\title{
The role of macro-aggregation in regulating enzymatic depolymerization of soil organic nitrogen
}

Article

Accepted Version

Creative Commons: Attribution-Noncommercial-No Derivative Works 4.0

Fukumasu, J. and Shaw, L. (2017) The role of macroaggregation in regulating enzymatic depolymerization of soil organic nitrogen. Soil Biology and Biochemistry, 115. pp. 100108. ISSN 0038-0717 doi:

https://doi.org/10.1016/j.soilbio.2017.08.008 Available at https://centaur.reading.ac.uk/71814/

It is advisable to refer to the publisher's version if you intend to cite from the work. See Guidance on citing.

To link to this article DOI: http://dx.doi.org/10.1016/j.soilbio.2017.08.008

Publisher: Elsevier

All outputs in CentAUR are protected by Intellectual Property Rights law, including copyright law. Copyright and IPR is retained by the creators or other copyright holders. Terms and conditions for use of this material are defined in the End User Agreement.

www.reading.ac.uk/centaur 
Central Archive at the University of Reading

Reading's research outputs online 


\section{Title}

2 The role of macro-aggregation in regulating enzymatic depolymerization of soil organic 3 nitrogen.

4

\section{$5 \quad$ Author names and affiliations}

6 Jumpei Fukumasu ${ }^{\mathrm{a}, \mathrm{b}}$, Liz J. Shaw ${ }^{\mathrm{b}^{*}}$

7 a Graduate School of Environmental and Life Science, Okayama University, 3-1-1

8 Tsushimanaka, Okayama 700-8530, Japan

$9{ }^{\mathrm{b}}$ Soil Research Centre, Department of Geography and Environmental Science, School of 10 Archaeology, Geography and Environmental Science, University of Reading,

11 Whiteknights, P. O. Box 233, Reading RG6 6DW, UK

$12 *$ Corresponding author. Tel.: +44 (0) 118 3786971; fax: +44 (0) 118 3786666. E-mail 13 address: e.j.shaw@ reading.ac.uk (L.J. Shaw).

14

\section{Highlights}

16 Aggregation protection of polymeric organic N (PON) from enzyme attack explored

17 - Dis-macroaggregation significantly increased net anaerobic $\mathrm{N}$ mineralization rate

$18 \quad(\mathrm{Nmin})$

- PON depolymerase-Nmin relationships distinguish mechanisms responsible

20 Role of disaggregation-increased accessibility of substrate to enzymes revealed

21 - Factors promoting net Nmin on disaggregation may differ with land use 


\section{Abstract}

26 Extracellular enzymatic depolymerization of polymeric organic nitrogen (PON) is a rate-

27 limiting step in $\mathrm{N}$ mineralization. However, enzymatic accessibility to PON might be 28 regulated by physical occlusion of the PON resulting from the architectural packing of

29 soil minerals during aggregate formation. To examine the extent to which enzymatic 30 accessibility to PON is regulated by soil aggregation, we put forward a new approach

31 involving the comparison of relationships between potential $\mathrm{N}$ depolymerase activity 32 (protease and $\beta$-glucosaminidase; as an estimate of the potential to produce 33 depolymerized products) and net $\mathrm{N}$ mineralization (as a bioassay for actual low molecular 34 weight dissolved ON production) in aggregated and corresponding disaggregated soil. 35 Soils were sampled from grassland (GL) and arable land (AL), separated by dry sieving 36 into fractions (4.75-2, 2-0.25 and $0.25-0.063 \mathrm{~mm})$ and fractions mixed (4:4:1 by mass, 37 respectively) to obtain constructed aggregated soils. Corresponding disaggregated soils 38 were prepared using a mortar and pestle. This procedure mainly disrupted the $4.75-2 \mathrm{~mm}$ 39 (large macro-aggregate) fraction. Disaggregation significantly promoted $(\mathrm{p}<0.05)$ net $40 \mathrm{~N}$ mineralization rates by 1.3 times and 1.5 times in GL and AL soil, respectively. When 41 net $\mathrm{N}$ mineralization - potential $\mathrm{N}$ depolymerase relationships for GL were examined, a 42 greater slope parameter for disaggregated compared to aggregated soil $(\mathrm{p}=0.001$; 43 ANCOVA) quantified the extent to which this promoted $\mathrm{N}$ mineralization could be 44 attributed to disruption of macroaggregate-increased enzymatic accessibility to PON. For 
$45 \mathrm{AL}$, which had low protease and $\beta$-glucosaminidase activity, promoted $\mathrm{N}$ mineralization

46 rate could not be attributed to increased protease $+\beta$-glucosaminidase accessibility to

47 PON reflecting a possible role for other $\mathrm{N}$ depolymerases and/or osmolyte/lysate effects.

48 By proposing how differences between mineralization-depolymerase relationships for

49 soils differing in aggregation status might, with assumptions, be interpreted to identify

50 the role of physical occlusion in protection of PON, we give new insight on the regulation

51 of enzymatic depolymerization by physical protection through macro-aggregation for 52 soils from contrasting land use.

53

54 Keywords: Nitrogen mineralization, extracellular enzymes, soil macro-aggregation, 55 bioaccessibility, enzymatic depolymerization

\section{$57 \quad 1$ Introduction}

59 Nitrogen $(\mathrm{N})$ availability is the most important factor for ecosystem productivity, and soil

60 organic matter $(\mathrm{OM})$ is a sink and source of nitrogen for plants (Schulten and Schnitzer,

61 1998). In surface soil, up to $90 \%$ of nitrogen is stored as organic $\mathrm{N}$ in soil OM (Olk, 2008).

62 The transformation of polymeric organic $\mathrm{N}(\mathrm{PON})$ to plant available forms depends

63 initially on depolymerization mediated by extracellular enzymes (Geisseler et al., 2010)

64 to yield monomeric/lower molecular weight dissolved organic N (LMW DON) which

65 already may be plant-available (Schimel and Bennett, 2004; Jones et al., 2005) and also

66 readily mineralizable to inorganic N (Schimel and Bennett, 2004). These extracellular 
67 enzymes may be of microbial, plant and animal origin (Vranova et al., 2013) and the 68 depolymerization process appears to be the rate-limiting step in $\mathrm{N}$ mineralization 69 (Schimel and Bennett, 2004; Jan et al., 2009).

71 However, depolymerization of PON could be regulated not only by the biochemical 72 reactions described above but also by physical and chemical factors that alter the 73 accessibility of PON substrates to the extracellular enzymes that act on them. While 74 representing a chemical continuum of structures derived from the progressive 75 decomposition of organic macromolecules, soil $\mathrm{OM}$ (with constituent $\mathrm{N}$ ) has been 76 conceptualised as belonging to discrete pools differing in their susceptibility to 77 decomposition and the mechanisms by which the OM is stabilized, namely: (i) physical 78 inaccessibility through occlusion within soil mineral or aggregate architecture; (ii) 79 chemical interaction between OM and inorganic constituents (e.g., sorption, organo-metal 80 cheletion) (Sollins et al. 1996). Polymeric OM could also be biochemically inaccessible 81 to enzymatic attack through inherent or acquired recalcitrance of chemical structure (Six 82 et al. 2002) but the importance of biochemical stabilization through molecular 83 recalcitrance of soil OM has been questioned quite recently and greater importance given 84 to the influences of physical occlusion and chemical interaction (Six et al., 2004; Schmidt 85 et al., 2011; Dungait et al., 2012; Lehmann and Kleber, 2015). Much of the discussion of 86 the mechanisms of persistence of soil OM have been focused on organic carbon, however, 87 the accessibility of soil PON to enzymatic depolymerization might also be viewed within 88 the same framework (Olk, 2006; Brzostek and Finzi, 2011). It is well established that 
soils contain significant potential activity of depolymerases that are involved in the

90 breakdown of the proteinaceous and chitinaceous OM (Allison and Jastrow, 2006;

91 Geisseler et al., 2010; Vranova et al., 2013) that represents a significant proportion of soil

92 PON (Geisseler et al., 2010). However, the extent to which physical occlusion and

93 mineral associations prevents this activity from being realized with respect to $\mathrm{N}$

94 mineralization has not been explicitly examined (Benbi and Richter, 2002).

95

96 A significant mechanism for the physical occlusion of OM results from the architectural

97 packing of soil minerals during aggregate formation (Golchin et al., 1994), which traps

98 OM within pores created. Previous studies have reported that disaggregating soil structure,

99 either through soil tillage or by soil physical treatments imposed in the laboratory,

100 promotes $\mathrm{N}$ mineralization (Cabrera and Kissel, 1988; Balesdent et al., 2000). This

101 disaggregation-promoted $\mathrm{N}$ mineralization might be consistent with the suggested role

102 that physical occlusion within aggregates plays in limiting the accessibility of PON for

103 decomposition. However, this promotion might also occur due to the physiological

104 release of mineralizable osmolytes by microbial cells in response to disaggregation, for

105 example, on exposure of cells that were previously inside aggregates to dehydration and

106 rewetting (Navarro-García et al., 2012; Borken and Matzner, 2009; Halverson et al., 2000;

107 Fierer and Schimel et al., 2002) or as a result of the rupture of macroaggregate-binding

108 fungal hyphae (Jastrow et al., 2007; Hobbie and Hobbie 2012). Quantifying the

109 contribution of the release of PON from physical constraints to depolymerisation to the

110 promotion of $\mathrm{N}$ mineralization on disaggregation, to our knowledge, has not previously 
111 been attempted, potentially due to lack of approaches to untangle this contribution from

112 that of the mineralization of osmolytes/lysates produced as a result of disaggregation.

113

114 Accordingly, our overall aim is to better understand the extent to which the promotion of

$115 \mathrm{~N}$ mineralisation following the disruption of soil aggregates can be explained by release

116 of PON from physical constraints to depolymerisation rather than by osmolyte/lysate

117 release. To do this, we put forward an approach involving the comparison of

118 relationships between potential $\mathrm{N}$ depolymerase activity (as an estimate of the potential

119 to produce depolymerized products) and net $\mathrm{N}$ mineralization (as a bioassay for actual

120 LMW DON production) in aggregated and corresponding disaggregated soil. We apply

121 this analysis to grassland and arable soil with the additional aim of understanding how

122 the contribution of PON release to the flush in $\mathrm{N}$ mineralization on disaggregation varies

123 with land use.

124

1252 Materials and Methods

126

2.1 Soil sampling and construction of "aggregated" and "disaggregated" soils

128

129 Soil samples (0 to $\sim 20 \mathrm{~cm}$ depth) were taken from random locations within grassland

$130(\mathrm{GL} ; \mathrm{N}=6)$ and arable (AL; N=5) fields from the University of Reading farm (Sonning,

131 Berkshire, U.K.; NGR: SU765765) on 15/05/2015. Following air-drying, “constructed

132 aggregated" soils were prepared by sieving to obtain $4.75-2 \mathrm{~mm}, 2-0.25 \mathrm{~mm}$ and $0.25-$ 
$1330.063 \mathrm{~mm}$ size fractions and then by mixing these fractions, on a mass basis, in the

134 following respective proportions: 4:4:1 (to approximately represent the proportions

135 initially present in GL soil, Supplementary Fig. 1). The size classes were chosen to

136 represent macro-aggregate $(2-0.25 \mathrm{~mm})$ and micro-aggregate $(0.25-0.063 \mathrm{~mm})$ fractions

137 (Six et al., 2000) and large macro-aggregates (4.75 to $2 \mathrm{~mm}$ ) and the same proportions of

138 these size classes were used for both soils so that we could examine land use effects on

139 the nature of the protection provided by aggregates with the same initial size distribution.

140 Corresponding "constructed disaggregated" soils were prepared by disruption of a

141 subsample of the constructed aggregated soil by grinding using a pestle and mortar until

142 no further disaggregation could be achieved, as judged by eye. Selected properties of

143 the constructed soils are shown in Table 1. Fig. 1 shows the percentage, on a mass basis,

144 of the four different fractions $(4.75-2 \mathrm{~mm}, 2-0.25 \mathrm{~mm}, 0.25-0.063 \mathrm{~mm}$ and $<0.063 \mathrm{~mm})$ in

145 the constructed soils prior to and after disaggregation. The constructed soils were kept

146 in the air-dried state at room temperature until sub-sampled for use in $\mathrm{N}$ mineralization

147 and enzyme assays. Sub-samples for enzyme assays were processed within 14 days of the

148 commencement of the net $\mathrm{N}$ mineralization assay.

\subsection{Net anaerobic $N$ mineralization}

152 Constructed aggregated and disaggregated soils $(54 \mathrm{~g})$ were put into $100 \mathrm{~mL}$ flasks and the

153 water content adjusted to $100 \%$ of water filled pore space (WFPS) as calculated using the

154 bulk density and a soil particle density of $2.6 \mathrm{~g} \mathrm{~cm}^{-3}$. After the flasks were flushed with 
$155 \mathrm{~N}_{2}$ gas for 2 minutes, the flasks were sealed with rubber stoppers and incubated at $26^{\circ} \mathrm{C}$

156 for 10 days. At the end of the incubation, inorganic $\mathrm{N}$ was extracted with $1 \mathrm{M} \mathrm{KCl}(200$

$157 \mathrm{ml}, 30 \mathrm{~min})$. The net $\mathrm{N}$ mineralization rate was determined by subtracting $\mathrm{NH}_{4}{ }^{+}$measured

158 at the beginning of the incubation (Day 0; Table 1) from $\mathrm{NH}_{4}{ }^{+}$concentration measured

159 on Day 10 (Hart et al., 1994) and expressed as mmol $\mathrm{N} \mathrm{kg}^{-1}$ OD-soil ${ }^{-1} 240 \mathrm{~h}^{-1}$.

160

161

\subsection{Potential N-acquiring enzyme activity assays}

162

163 Protease activity was determined by measuring the concentration of tyrosine produced

164 through depolymerization of Na-caseinate as described by Ladd and Butler (1972) and

165 Geisseler and Horwath (2008). Briefly, aggregated or disaggregated soils (1 g air-dried

166 basis) in autoclaved glass vials were amended with Tris buffer $(2.5 \mathrm{~mL}, \mathrm{pH} 8.0$ modified

167 with $1 \mathrm{M} \mathrm{HCl})$ and $\mathrm{Na}$-caseinate $(2.5 \mathrm{~mL}, 2 \%)$ and incubated at $50^{\circ} \mathrm{C}$ for 2 hours.

168 Trichloroacetic acid (TCA, $5 \mathrm{~mL}, 10 \%$ ) was then added to stop the reaction and a $1.5 \mathrm{~mL}$

169 aliquot centrifuged (16000 x g, 2 min.). $\mathrm{Na}_{2} \mathrm{CO}_{3}(0.9 \mathrm{~mL}, 1.4 \mathrm{M})$ and diluted Folin-

170 Ciocalteu reagent $(0.3 \mathrm{~mL}$, water: Folin-Ciocalteu $=3: 1$; Sigma-Aldrich $)$ were added to

171 an aliquot $(0.6 \mathrm{~mL})$ of the resulting supernatant and the absorbance at $680 \mathrm{~nm}$ determined

172 after 5 min. using a spectrophotometer. Blank incubations followed the above procedure

173 except Na-caseinate was added to the samples after the incubation and addition of TCA.

174 Blank readings provided an estimate of concentrations of tyrosine and other Folin-

175 Ciocalteu -reactive compounds native to soil (e.g. cysteine, tryptophan; Everette et al., 176 2010) and were subtracted from the readings from the caseinate-incubated samples to 
177 express protease activity as $\mu$ mol tyrosine equivalents $\mathrm{g}^{-1}$ OD-soil hour ${ }^{-1}$ after 178 comparison of absorbance $680 \mathrm{~nm}$ readings to a tyrosine calibration curve (0 to 2.76

$179 \mu$ mol tyrosine). A preliminary experiment showed that protease activity was linear with 180 incubation time (0-4 h).

$181 \beta$-glucosaminidase activity was determined by measuring the amount of $\rho$-nitrophenol 182 produced from the cleavage of $\rho$-Nitrophenyl-N-acetyl- $\beta$-D-glucosaminide $(\rho N N A G)$ as 183 described by Parham and Deng (2000). Briefly, constructed aggregated air-dried soils

184 (1g) were amended with acetate buffer $(4 \mathrm{~mL}, 100 \mathrm{mM}, \mathrm{pH} 5.5)$ and $\rho N N A G$ (1mL, $18510 \mathrm{mM}$ ) substrate solution and incubated at $37^{\circ} \mathrm{C}$ for 1 hour. After the incubation, $1 \mathrm{~mL}$ of $186 \mathrm{CaCl}_{2}(0.5 \mathrm{M})$ and $4 \mathrm{~mL} \mathrm{NaOH}(0.5 \mathrm{M})$ were added, the samples centrifuged $(1000 \times \mathrm{g}$,

$18710 \mathrm{~min}$.) and the supernatant taken for determination of absorbance at $405 \mathrm{~nm}$ using a 188 spectrophotometer. Blank incubations followed the above procedure except that $189 \rho N N A G$ was added after the incubation. Incubations including substrate but no soil

190 were also included. For constructed disaggregated soils the same procedure was

191 followed except that the assay was based on $0.5 \mathrm{~g}$ soil, with the volumes of buffer,

192 substrate and extractant solutions also reduced by a half. $\beta$-glucosaminidase activity was 193 expressed as $\mu$ mol $\rho$-nitrophenol $\mathrm{g}^{-1}$ OD-soil hour ${ }^{-1}$ through comparison of 194 spectrophotometer readings to a $\rho$-nitrophenol calibration curve $(0-1.08 \mu \mathrm{mol} \rho$ 195 nitrophenol).

196

$197 \quad 2.4 \quad$ Sample size and statistical analysis 
199 Soils from 6 and 5 locations for GL and AL, respectively, were sampled and the analysis 200 of soil properties, mineralization rates and enzymatic activities for constructed soils 201 within each location were conducted in triplicate from which a mean value for each 202 location was derived and used as the basis for statistical analysis.

203

204 Statistical analysis was conducted using IBM SPSS 22.0 STATISTICS and Statsmodels

205 package within Python ${ }^{\mathrm{TM}}$ 3.5. To compare the difference in soil properties between GL 206 and AL, Welch's t-test or t-test was used. To test for effect of physical treatment 207 (aggregated versus disaggregated) on (i) the production of native Folin-Ciocalteu 208 reactive compounds, (ii) individual and total enzymatic potential and (iii) net $\mathrm{N}$ 209 mineralization rate, paired t-tests, or, where data did or did not satisfy the assumption of 210 normality (Shapiro Wilk test), One sample Sign test of median was used. $P=0.05$ was 211 adopted as the significance level. Ordinary least squares regression models were 212 established for total enzyme activity (protease $+\beta$-glucosaminidase) versus net $\mathrm{N}$ 213 mineralization rate for GL, AL and GL + AL datasets, respectively. For datasets showing 214 a significant relationship (GL and GL+AL), ANCOVA was used to examine if slope 215 parameters for aggregated and disaggregated soils differed statistically under a model 216 assuming common intercepts and different slopes, which was the preferred specification 217 using both Akaike and Bayesian information criteria along with adjusted $\mathrm{R}^{2}$. $\mathrm{F}$ and 218 Breush-Pagan tests were used to verify assumptions of equality of error variances and 219 homoscedasticity, respectively. The normality of residuals was confirmed for 220 regression analysis. 


\section{Results and Discussion}

222 We sought to better understand the role that physical occlusion of PON plays in regulating $223 \mathrm{~N}$ mineralization. To do this, we quantified net $\mathrm{N}$ mineralization activity and PON 224 depolymerase potential in soils from two different land uses differing in aggregation 225 status (Table 2). Initial examination of the net $\mathrm{N}$ mineralization data for soil from both 226 land uses verified the expectation that disaggregation would significantly increase net $\mathrm{N}$ 227 mineralization (Table 2) as has been reported in many other studies (Cabrera and Kissel, 228 1988; Balesdent et al., 2000). The magnitude of the disaggregation-promoted increase 229 (1.3 times and 1.5 times in GL and AL soil, respectively) we recorded is within the range 230 (0.74 to 3.49 times) reported in a review of previous related studies (Balesdent et al., 231 2000).

233 3.1 The efficacy of the disaggregation treatment

235 The disaggregation treatment was imposed by grinding with a pestle and mortar which 236 resulted in the complete destruction of large macro-aggregates $(4.75-2 \mathrm{~mm})$ (Fig. 1) in 237 soil from both land uses with concomitant redistribution of soil mass to the $0.25-0.063$ $238 \mathrm{~mm}$ and $<0.063 \mathrm{~mm}$ size fractions. We did not distinguish primary particles from 239 aggregates in the resulting size fractions, but, the $<0.063 \mathrm{~mm}$ fraction, by definition, 240 would consist of silt- and clay-sized primary particles and micron-sized aggregates (Six 241 et al., 2000). From comparison of the size fraction distribution data (Fig. 1) with initial 242 soil textural information (Table 1), we deduce that the $2-0.25 \mathrm{~mm}$ and $0.25-0.063 \mathrm{~mm}$ 
243 fractions together could not have been comprised solely of primary particles (medium to 244 very coarse sand, very fine to fine sand, respectively) and therefore that some macro245 and/or micro-aggregates (produced following macro-aggregate disruption) remained 246 after the disaggregation treatment. In recognition of the predominant role that micro247 aggregates are suggested to play in physical protection of OM (Six et al., 2002), we 248 initially considered the use of a ball mill rather than a pestle and mortar to achieve greater 249 levels of dis-(micro)-aggregation (Pulleman and Marinissen, 2004). However, ball250 milling might alter soil particle properties such as specific surface area and reactivity 251 (Vdović et al., 2010) and therefore chemical and physicochemical binding between 252 PON/enzymes and soil mineral surfaces (Zimmerman and Ahn, 2011). Ball-milling 253 might also significantly reduce the particle size of PON. Such alterations would 254 confound isolation of the role of aggregation in PON protection through occlusion within 255 aggregate architecture, and therefore crushing with a pestle was chosen as a gentler 256 method that might also result in a level of dis-(macro)-aggregation that more closely 257 resembles that brought about on soil disturbance by tillage (Six et al., 2004).

3.2 Understanding the role of physical occlusion of PON in regulating $\mathrm{N}$ mineralization.

261 As previously discussed (Section 1), the disaggregation-promoted mineralization we 262 recorded (Table 2) might be due not only to increased accessibility of PON (i.e. release 263 from occlusion) to depolymerizing enzymes but also due to mineralization of microbial compounds that were released on disaggregation as a result of physiological adaptations 
265 to dehydration (osmolyte production) by microbes previously protected within aggregates 266 or rupture of fungal hyphae (lysate production) on disaggregation.

268 In order to distinguish between osmolyte/lysate- and accessibility-related mechanisms, 269 we examined the relationships between potential $\mathrm{N}$ (combined protease and $\beta$ 270 glucosaminidase) depolymerase activity (as an estimate of the potential to produce 271 depolymerized LMW DON) and net $\mathrm{N}$ mineralization (as a proxy or bioassay for actual 272 LMW DON production) in aggregated and corresponding disaggregated soils (Fig. 2).

273 We suggest that intercept and slope parameters derived from linear regressions between 274 these variables for aggregated and disaggregated states (Table 3) can be interpreted and 275 compared to help distinguish between the mechanisms responsible for disaggregation276 promoted $\mathrm{N}$ mineralization. Our assumptions (section 3.2.1) and interpretations of the 277 regression parameters (section 3.2.2; Fig. 2a) are discussed below.

3.2.1 Assumptions

280 The use here of net $\mathrm{N}$ mineralization as a bioassay for the production of LMW DON 281 (whether by depolymerization of PON or as osmolytes/lysates) assumes that, firstly, 282 LMW DON production (and not microbial uptake of, and release of inorganic $\mathrm{N}$ from, $283 \mathrm{DON}$ ) is the rate-limiting step to net $\mathrm{N}$ mineralization (Schimel and Bennet, 2004; 284 Kuzyakov et al., 2009), i.e. as soon as LMW DON is produced, it is rapidly mineralized 285 and detected as ammonium N. The validity of this assumption is supported by studies 286 showing that free amino acids do not accumulate in soil, implying rapid microbial 
turnover (Jones et al., 2004), and also that the mineralization rate of protein added to soil 288 is significantly slower than that of amino acid (Jan et al., 2009). Both these studies 289 suggest that the bottleneck of the soil $\mathrm{N}$ cycle is the production of LMW DON, not its 290 uptake and mineralization.

292 Secondly, by using net N mineralization as a bioassay for the production of LMW DON 293 in the context of examining the effect of aggregation on enzymatic accessibility to PON, 294 we also make an assumption about the ability of the bioassay to bioreport on DON 295 production with an efficiency that is not affected by the aggregation status of the soil. 296 This efficiency of bioreporting is related to the relative contributions of the processes of 297 gross $\mathrm{N}$ mineralization and gross $\mathrm{N}$ immobilization in defining the concentration of 298 ammonium quantified as net $\mathrm{N}$ mineralization in our bioassay. Out of the various 299 mineralization-immobilization pathway schemes previously conceptualized (Manzoni 300 and Porporato, 2009), we adopt the model that gross $\mathrm{N}$ mineralization occurs following 301 the cellular assimilation of LMW DON and is a result of the subsequent release of $\mathrm{N}$ to 302 the mineral pool that is surplus to requirements. The ammonium production that is 303 measured in our net $\mathrm{N}$ mineralization assay reflects the balance between the production 304 of this surplus $\mathrm{N}$ and gross immobilization and it is this balance we assume that is not 305 affected by soil aggregation status. In addition to the decomposition flux of LMW DON 306 substrate (most simply considered as a function of substrate concentration and rate of 307 decomposition), this balance is a function of the substrate $\mathrm{C}: \mathrm{N}$ ratio and the critical 308 substrate $\mathrm{C}: \mathrm{N}$ ratio (which depends on characteristics of the microbial biomass: biomass 
309 C:N and the efficiency with which substrate $\mathrm{C}$ is respired) (Manzoni and Porporato, 2009).

310 Thus, underlying the assumption that the efficiency of the bioreporting of LMW DON

311 production by the net $\mathrm{N}$ mineralization assay is not affected by soil aggregation status,

312 are the assumptions that the following properties are not affected: (i) the C:N quality of

313 the available substrate and (ii) biomass characteristics ( $\mathrm{C}: \mathrm{N}$ and $\mathrm{C}$ use efficiency).

314 Studies that have employed fractionation to isolate $\mathrm{OM}$ associated with different soil

315 physical locations have shown that the $\mathrm{C}: \mathrm{N}$ of particulate $\mathrm{OM}$ to be fairly constant, 316 regardless of its physical location (i.e. whether it was free or within macroaggregates

317 (Leifeld and Kögel-Knabner, 2005; Liao et al., 2006; Marriott and Wander, 2006)).

318 Such findings are potentially supportive of the assumption (i) of unaltered substrate

319 quality on disaggregation. With regards to assumption (ii), as previous research has

320 shown effects of soil physical disruption, in this case sieving, on microbial community

321 structure (Thompson et al. 2010), we cannot rule out that changes in microbial community

322 composition on disaggregation occurred in our experiment and that this changed

323 community had altered characteristics with respect to biomass $\mathrm{C}: \mathrm{N}$ and $\mathrm{C}$ use efficiency.

324 In addition, the above discussion has assumed that changes in biomass size (growth or 325 decay) are negligible. These last uncertainties should be kept in mind when judging our 326 later interpretations (section 3.2.2). Further development of the methodological concept 327 introduced here should involve quantification of the gross process of mineralization and 328 dynamics of the microbial biomass throughout the mineralization incubation.

330 A final assumption underpinning our interpretation is that the potential $\mathrm{N}$ depolymerase 
331 assays employed determine the same pool of potentially active enzymes regardless of 332 aggregation status, i.e. that the active enzyme pool had access to saturating substrate 333 concentrations during the assay incubation. This, as is the basis for all soil depolymerase 334 assay methods, was facilitated here through addition of excess and freely dissolved 335 substrate and incubation under slurry conditions to limit diffusional constraints 336 (Wallenstein and Weintraub, 2008). To support this assumption, comparison of 337 depolymerase activities between aggregated and disaggregated soil (Table 2) reveals no 338 effect of aggregation on individual (protease and $\beta$-glucosaminidase) and total (protease 339 plus $\beta$-glucosaminidase) activities, with just one exception (protease in GL soil). Potential 340 explanations for why protease activity in disaggregated GL soil was decreased are 341 discussed in the supplementary material.

343 3.2.2 Interpretation of regression parameters to distinguish accessibility-related (slope)

344 from other (intercept) contributions to disaggregation-promoted net $\mathrm{N}$ mineralization.

346 As depicted in Fig. 2a, the intercept term extrapolates the relationship between PON 347 depolymerase potential and net $\mathrm{N}$ mineralization to the case where PON depolymerase 348 (protease $+\beta$-glucosaminidase) potential is zero. The magnitude of the intercept can thus 349 be interpreted to represent the production of LMW DON (and its subsequent net 350 mineralization) that is independent of protease $+\beta$-glucosaminidase potential. An 351 intercept that is significantly different from zero might reflect the role of 'other' 352 depolymerases whose activity was not quantified. Whilst chitin and protein are 
353 considered major PON sources for soil N supply (Geisseler et al., 2010) and therefore, 354 together, protease and $\beta$-glucosaminidase reflect important activity degrading polymeric $355 \mathrm{~N}$, there are other enzyme classes that might be involved in PON depolymerisation in soil, 356 such as nucleases. In addition, a non-zero intercept might reflect a contribution from 357 the mineralization of non-polymeric $\mathrm{N}$ (e.g. amino acids, $\mathrm{N}$-acetylglucosamine), but, this 358 contribution in at least the aggregated soils would not be significant under the assumption 359 of depolymerisation-limited $\mathrm{N}$ mineralization, as just discussed (section 3.2.1). The 360 difference between intercept terms for the aggregated versus disaggregated states 361 quantifies the impact of the physical disruption of aggregates on protease $+\beta$ 362 glucosaminidase-independent $\mathrm{N}$ mineralization (Fig. 2a). For illustration, applying this 363 interpretation to the regression analysis of data for AL and GL soils combined (Fig. 2b, 364 Table 3) reveals that, for aggregated soil, the intercept term was insignificant, supporting 365 the importance of protease and $\beta$-glucosaminidase potential for net $\mathrm{N}$ mineralization. 366 However, the intercept term for disaggregated soil indicates that a significant amount of $367 \mathrm{~N}$ mineralization occurred independently of the potential activity of proteases and $\beta$ 368 glucosaminidases. An increase in the intercept on disaggregation might reflect an 369 increased role for 'other' depolymerases in $\mathrm{N}$ mineralization (i.e. non-protease/ $\beta$ 370 glucosaminidase enzymes or new proteases and $\beta$-glucosaminidases produced during the 371 incubation) in the disaggregated soil, or, the mineralization of LMW DON compounds 372 that were released (independently of depolymerase activity) in response to disaggregation. 373 This latter might have occurred as a result of osmolyte/lysate production discussed above, 374 or, as a result of the release of physically sequestered labile $\mathrm{N}$ that was previously not 
375 accessible (Darrouzet-Nardi and Weintraub, 2014). Enhancement of the F-C reactive 376 compound pool (which represents concentrations of N-containing monomers such as 377 cysteine, tryptophan, tyrosine, guanine alongside a variety of other antioxidant 378 compounds (Everette et al. 2010; Table 2) by such a release of non-polymeric $\mathrm{N}$ on 379 disaggregation would not necessarily be expected due to rapid monomer turnover (Jones 380 et al., 2004) and therefore we do not have evidence to support one explanation over 381 another for the protease $+\beta$-glucosaminidase - independent $\mathrm{N}$ mineralization suggested 382 by the regression analysis.

383

384 As also depicted in Fig. 2a, the slope parameter quantifies the extent to which net $\mathrm{N}$ 385 mineralization increases for a given increase in PON depolymerase potential (protease $+\beta$ 386 glucosaminidase). It is suggested that the magnitude of this parameter represents the 387 extent to which PON depolymerase potential (protease $+\beta$-glucosaminidase) is realized 388 for the production of LMW DON, as bioreported by the net $\mathrm{N}$ mineralization assay. 389 Critical to our original aim, it follows that the difference between slope parameters for 390 soils differing in aggregation status can be used to quantify the role of aggregate occlusion, 391 and, in our case mostly macroaggregate (section 3.1) occlusion, of PON in constraining 392 PON depolymerization and subsequent net mineralization. Applying this interpretation 393 to the combined GL+AL data (Fig. 2b, Table 3), it can be seen that the slope for the 394 disaggregated soils is statistically greater (according to ANCOVA, $\mathrm{p}<0.001$ ) than that for 395 the aggregated soil. Thus, more depolymerase potential is realized for mineralization in 396 disaggregated soil and we interpret that this greater realization of potential is due to 
397 greater accessibility of PON following its release from physical protection. We believe 398 that the disaggregation treatment disrupted and homogenized the within- (mainly macro-) 399 aggregate pore network, particularly through opening pore 'throat' restrictions to 400 accessibility (Mayer et al., 2004; Ewing et al., 2006). There is a possibility, however, 401 that our (manual pestle and mortar) method of disaggregation also resulted in some 402 reduction in particle size of PON. This possibility and the subsequent consequences for 403 net $\mathrm{N}$ mineralization and the slope parameter for disaggregated soil remain to be tested 404 for our samples. However, previous work has inferred that breakdown of soil structure 405 and not fragmentation of plant residues explains the mineralization flush in crushed soils 406 (Chevallier et al., 2011). Additional studies on the effect of plant residue particle size 407 on decomposition and mineralization produce variable conclusions (Ambus and Jensen, 408 1997; Bending and Turner, 1999; Vestergaard et al., 2001; Bhupinderpal et al., 2006; 409 Toenshoff et al., 2014) with some studies suggesting no effect of residue particle size on 410 decomposition and $\mathrm{N}$ dynamics depending on interactions with other factors such as 411 residue quality and incubation time (Ambus and Jensen, 1997; Bending and Turner, 1999;

412 Vestergaard et al., 2001; Toenshoff et al., 2014). Consequently, in our system, we favour 413 the breakdown of soil structure as a significant contributor to the increased slope for the 414 disaggregated soils.

415 It is relevant to note here that since our net $\mathrm{N}$ mineralization assay was 416 conducted at a moisture content of $100 \%$ WFPS, the access of $\mathrm{N}$ depolymerases to their 417 substrates would not be constrained by lack of hydrological connectivity within the soil 418 and therefore that the (release from) physical protection that was assayed for here was a 
419 function solely of the structure (connectivity) of the pore network. This situation of 420 constant moisture content is distinct from dynamic wetting and drying cycles likely 421 encountered under field conditions where variable hydrological disconnectivity in 422 addition to pore network disconnectivity would play a role in protecting PON from 423 enzymatic attack.

$425 \quad 3.3$ The impact of land use.

427 Initial comparison of net $\mathrm{N}$ mineralization and potential $\mathrm{N}$ depolymerase activities 428 between GL and AL (Table 2, comparisons done for aggregated soils) revealed that net $\mathrm{N}$ 429 mineralization activity and potential $\beta$-glucosaminidase activity were significantly higher 430 in GL than in AL soil and this presumably reflects the higher total C and $\mathrm{N}$ contents in 431 GL soil (Table 1). In particular, $\beta$-glucosaminidase activity was approximately ten-fold 432 higher in GL than in AL, suggesting that chitin concentrations, as a major substrate for $\beta$ 433 glucosaminidase, are low in AL soil, possibly because of tillage effects on soil fungal 434 populations (Jastrow et al., 2007 ; Gupta and Germida, 2015). The magnitude of the 435 land use effect on $\beta$-glucosaminidase contrasts to that of protease $(P=0.059$, only $\sim 1.6$ 436 fold increase in GL) and, given that enzyme production is regulated in response to the 437 availability of substrates (Geisseler et al., 2010), this contrast suggests that PON quality 438 differs between AL and GL.

440 To understand the impact of land use on the N depolymerase-accessibility of PON, the 
441 relationships between net $\mathrm{N}$ mineralization and $\mathrm{N}$ depolymerase potential for GL and AL 442 soils were examined individually (Fig 3a and b; Table 3). For disaggregated GL soil 443 (Fig 3a), there was a strong significant relationship between net $\mathrm{N}$ mineralization and 444 depolymerase potential $\left(\mathrm{P}=0.005, \mathrm{R}^{2}=0.86\right)$ while for aggregated GL soil the evidence 445 for a positive relationship was weaker $\left(\mathrm{P}=0.081, \mathrm{R}^{2}=0.47\right)$ with the slope coefficient 446 significantly ( $\mathrm{p}=0.001$, ANCOVA) lower than that for disaggregated soil. The 447 intercepts for both aggregated and disaggregated GL soil are not significant. Applying the 448 interpretation already discussed (section 2.3.2; Fig. 2) suggests that in the GL soil, the 449 disaggregation-promoted net $\mathrm{N}$ mineralization might be explained as a function of 450 increased accessibility of PON to proteases and $\beta$-glucosaminidase rather than other 451 mechanisms such as osmolyte/lysate production or an increased role of 'other' enzymes 452 in depolymerization. As also already discussed (section 3.2.1), this interpretation assumes that there is no difference in biomass turnover contributions to the measured net

$454 \mathrm{~N}$ mineralization between physical treatments. It is possible, for example, through 455 disaggregation-enhanced trophic interactions (i.e. increased access to prey for bacterial 456 predators in disaggregated soil; Young and Ritz, 2000) that this assumption was not met. 457 As cell debris provides a source of PON (Miltner et al., 2012) which would comprise 458 substrates ( $\mathrm{N}$-acetylglucosamine/proteins) and non-substrates for the enzymatic potential 459 we determined, any differences in cell turnover between physical treatments might be 460 reflected in differences between both gradient and intercept terms, respectively.

462 In contrast to the GL soils, the relationship between net mineralization and depolymerase 
463 potential was not significant for either aggregated $(\mathrm{P}=0.435)$ or disaggregated $(\mathrm{P}=0.241)$

464 AL soils (Fig 3b, Table 3). A larger sample size might have increased statistical power 465 to detect relationships, but, the data obtained suggests that depolymerization through 466 protease and $\beta$-glucosaminidase is not important for $\mathrm{N}$ mineralization in $\mathrm{AL}$ soil, 467 irrespective of aggregation status. As discussed above, the quality of PON in AL soil 468 may differ to that in GL. Different PON quality may be partly attributed to different 469 aggregate cycles between land use soil types (Six et al., 2000; Balesdent et al., 2000). 470 Because of likely shorter longevity of macro-aggregates in AL as a result of tillage, PON 471 in AL might have been exposed to a greater degree of microbial processing to forms that 472 are not accessible or not substrates for $\beta$-glucosaminidase and protease. For example, 473 such microbial processing may have led to: (i) a more intimate association of 474 proteinaceous and chitinaceous microbial residues with mineral phases and thereby their 475 protection through chemical interaction (Miltner et al; 2012; Bingham and Cotrufo, 476 2016); or, (ii) creation of organic $\mathrm{N}$ structures (e.g. heterocyclic N, Leinweber et al., 2013) 477 that are not recognized as substrates by $\beta$-glucosaminidase and protease. That potential $478 \quad \beta$-glucosaminidase and protease activity could be detected in AL, even though it was 479 apparently uncoupled from current availability of suitable substrates, might be explained 480 by the relative longevity of extracellular enzymes in the soil environment, their potential 481 activity thus integrating historical substrate conditions (Burns et al., 2013). Due to the 482 lack of significance for AL, we are not able to interpret the mechanisms responsible for 483 the disaggregation-promoted $\mathrm{N}$ mineralization flush seen for this soil (Table 2) in the 484 context of increased access of $\beta$-glucosaminidase / protease to substrates (Fig. 3b). We 
485 speculate in this case that the flush is a function of either osmolyte/lysate production or 486 release of non-proteinaceous/ chitinaceous PON for 'other' depolymerase attack or a 487 combination of both.

\section{Conclusions}

490 In the present study, net $\mathrm{N}$ mineralization rates for GL and AL soils were promoted 491 significantly by disruption of mainly large macro-aggregates $(4.75-2 \mathrm{~mm})$. We 492 hypothesized that these increased net $\mathrm{N}$ mineralization rates would be attributable to 493 increased accessibility of PON to extracellular enzymes (protease and $\beta$ 494 glucosaminidase) with the assumption that enzymatic depolymerization is a rate-limiting 495 step in overall $\mathrm{N}$ mineralization. It has been pointed out that micro-aggregate structure 496 is more important in protecting SOM (Six et al., 2002). However, we present evidence 497 to suggest that in the short term (e.g. 10 days), macro-aggregates in a grassland soil 498 contribute to the regulation of enzymatic accessibility to their substrates. For an arable 499 soil, the situation was less clear; with low concentrations of protease and $\beta$ 500 glucosaminidase, other depolymerase enzymes or increased availability of LMW DON 501 could be important in the promotion of $\mathrm{N}$ mineralization upon disruption of macro502 aggregates. More research on regulation of enzymatic depolymerization by soil structure 503 is useful for improved understanding of $\mathrm{N}$ dynamics through empirical studies and for 504 models incorporating enzymatic depolymerization as a key process in the $\mathrm{N}$ cycle (e.g. 505 Schimel and Weintraub, 2003). Here we suggest how differences between 506 mineralization-depolymerase relationships for soils differing in aggregation status might, 
507 with assumptions, be interpreted to identify the role of physical occlusion in protection 508 of PON from mineralization (Section 3.2; Fig. 2). The same approach might also be 509 useful for understanding physical constraints to organic carbon mineralization in soil. 510 


\section{Acknowledgements}

512 We thank technical support from Dr. Geoff Warren, Karen Gutteridge, Anne Dudley,

513 Franz Street, Richard Tegg, David Thornley, Alice Ughi, James Lamburn and Sue

514 Munroe. We thank Prof. Kelvin Balcombe for statistical advice. We also thank two

515 anonymous reviewers for their constructive comments, which helped us to improve the

516 manuscript. JF was partially funded by Japan Public-Private Partnership Student

517 Study Abroad Program, Ministry of Education, Culture, Sports, Science and technology

518 (MEXT) and British Council while in Reading, UK. Prof. Yasushi Mori at Okayama

519 University gave us valuable comments on our manuscript. LJS would like to dedicate

520 this paper in memory of her father, Prof. Ronald Shaw (1929-2016).

521

522

523 


\section{References}

525

526 Allison, S.D., Jastrow, J.D., 2006. Activities of extracellular enzymes in physically 527 528 529 isolated fractions of restored grassland soils. Soil Biology and Biochemistry 38, 3245-3256.

Ambus, P., and Jensen, E.S. (1997) Nitrogen mineralization and denitrification as influenced by crop residue particle size. Plant and Soil 197, 261-270.

Balesdent, J., Chenu, C., Balabane, M., 2000. Relationship of soil organic matter dynamics to physical protection and tillage. Soil \& Tillage Research 53, 215-230.

Benbi, D., Richter, J., 2002. A critical review of some approaches to modelling nitrogen mineralization. Biology and Fertility of Soils 35, 168-183.

Bending, G.D., and Turner, M.K. (1999) Interaction of biochemical quality and particle size of crop residues and its effect on the microbial biomass and nitrogen dynamics following incorporation into soil. Biology and Fertility of Soils 29, 319-327.

Bhupinderpal, S., Rengel, Z., and Bowden, J.W. (2006) Carbon, nitrogen and sulphur cycling following incorporation of canola residue of different sizes into a nutrientpoor sandy soil. Soil Biology \& Biochemistry 38, 32-42.

Bingham, A.H., Cotrufo, M.F., 2016. Organic nitrogen storage in mineral soil: Implications for policy and management. Science of The Total Environment 551, $116-126$.

Borken, W., Matzner, E., 2009. Reappraisal of drying and wetting effects on C and N mineralization and fluxes in soils. Global Change Biology 15, 808-824.

Brzostek, E.R., Finzi, A.C., 2011. Substrate supply, fine roots, and temperature control proteolytic enzyme activity in temperate forest soils. Ecology 92, 892-902. 
557 Burns, R.G., DeForest, J.L., Marxsen, J., Sinsabaugh, R.L., Stromberger, M.E.,

558 Wallenstein, M.D., Weintraub, M.N., Zoppini, A., 2013. Soil enzymes in a

559 changing environment: Current knowledge and future directions. Soil Biology and

560 Biochemistry 58, 216-234.

561

562 Cabrera, M.L., Kissel, D.E., 1988. Potentially Mineralizable Nitrogen in Disturbed and 563 Undisturbed Soil Samples. Soil Science Society of America Journal 52, 10105641015.

565

566 Chevallier, T., Blanchart, E., Toucet, J.M, Bernoux, M., 2011. Methods to estimate aggregate protected soil organic carbon 2: Does the grinding of the plant residues affect the estimations of the aggregate protected soil organic carbon? Communications in Soil Science and Plant Analysis 42, 1537-1543.

Darrouzet-Nardi, A., Weintraub, M.N., 2014. Evidence for spatially inaccessible labile $\mathrm{N}$ from a comparison of soil core extractions and soil pore water lysimetry. Soil 573 Biology and Biochemistry 73, 22-32.

Dungait, J.A.J., Hopkins, D.W., Gregory, A.S., Whitmore, A.P., 2012. Soil organic matter turnover is governed by accessibility not recalcitrance. Global Change Biology 18, 1781-1796.

Everette, J.D., Bryant, Q.M., Green, A.M., Abbey, Y.A., Wangila, G.W., Walker, R.B., 581

Ewing, S.A., Sanderman, J., Baisden, W.T., Wang, Y., Amundson, R., 2006. Role of 2010. Thorough study of reactivity of various compound classes toward the FolinCiocalteu reagent. Journal of Agricultural and Food Chemistry 58, 8139-8144.

Fierer, N., Schimel, J.P., 2002. Effects of drying-rewetting frequency on soil carbon and nitrogen transformations. Soil Biology and Biochemistry 34, 777-787. 
590 Geisseler, D., Horwath, W.R., 2008. Regulation of extracellular protease activity in soil 591 in response to different sources and concentrations of nitrogen and carbon. Soil 592 Biology and Biochemistry 40, 3040-3048.

593

594 Geisseler, D., Horwath, W.R., Joergensen, R.G., Ludwig, B., 2010. Pathways of 595 nitrogen utilization by soil microorganisms - A review. Soil Biology and 596 Biochemistry 42, 2058-2067.

597

598 Golchin, A., Oades, J.M., Skjemstad, J.O., Clarke, P., 1994. Soil structure and carbon 599

600

601

602

603

604

Gupta, V.V.S.R., Germida, J.J., 2015. Soil aggregation: Influence on microbial biomass cycling. Soil Research 32, 1043-1068.

605

606

Halverson, L.J., Jones, T.M., Firestone, M.K., 2000. Release of Intracellular Solutes by 607 and implications for biological processes. Soil Biology and Biochemistry. 80, A3A9.

608 Four Soil Bacteria Exposed to Dilution Stress. Soil Science Society of America

609

610

Hart, S.C., Stark, J.M., Davidson, E.A., Firestone, M.K., 1994. Nitrogen mineralization, 611

612 immobilization, and nitrification. In: Weaver, R.W., et al. (Eds.) Methods of Soil

613 Analysis, Part 2: Microbiological and Biochemical Properties. SSSA Book Series

614

615 Hobbie, J.E., Hobbie, E.A., 2012. Amino acid cycling in plankton and soil microbes

616 studied with radioisotopes: Measured amino acids in soil do not reflect

617 bioavailability. Biogeochemistry 107, 339-360.

618

619 Jan, M.T., Roberts, P., Tonheim, S.K., Jones, D.L., 2009. Protein breakdown represents 620 a major bottleneck in nitrogen cycling in grassland soils. Soil Biology and 621 Biochemistry 41, 2272-2282. 
623 Jastrow, J.D., Amonette, J.E., Bailey, V.L., 2007. Mechanisms controlling soil carbon

624 turnover and their potential application for enhancing carbon sequestration.

625 Climatic Change 80, 5-23.

626

627 Jones, D.L., Healey, J.R., Willett, V.B., Farrar, J.F., Hodge, A., 2005. Dissolved organic

628 nitrogen uptake by plants—an important $\mathrm{N}$ uptake pathway? Soil Biology and

629 Biochemistry 37, 413-423.

630

631 Jones, D.L., Shannon, D., Murphy, D. V., Farrar, J., 2004. Role of dissolved organic

632 nitrogen (DON) in soil N cycling in grassland soils. Soil Biology and Biochemistry

$633 \quad 36,749-756$.

634

635 Kuzyakov, Y., Blagodatskaya, E., Blagodatsky, S., 2009. Comments on the paper by

$636 \quad$ Kemmitt et al. (2008) "Mineralization of native soil organic matter is not regulated

637 by the size, activity or composition of the soil microbial biomass - A new

638 perspective" [Soil Biology \& Biochemistry 40, 61-73]: The biology of the

639 Regulatory Gate. Soil Biology and Biochemistry 41, 435-439.

640

641 Ladd, J.N., Butler, J.H.A., 1972. Short-term assays of soil proteolytic enzyme activities

642 using proteins and dipeptide derivatives as substrates. Soil Biology and

643 Biochemistry 4, 19-30.

644

645 Lehmann, J., Kleber, M., 2015. The contentious nature of soil organic matter. Nature $646528,60-8$.

647

648 Leifeld, J., Kögel-Knabner, I., 2005. Soil organic matter fractions as early indicators for 649 carbon stock changes under different land-use? Geoderma 124, 143-155.

650

651 Leinweber, P., Kruse, J., Baum, C., Arcand, M., Knight, J.D., Farrell, R., Eckhardt, 652 K.U., Kiersch, K., Jandl, G., 2013. Advances in Understanding Organic Nitrogen 653 Chemistry in Soils Using State-of-the-art Analytical Techniques. Advances in 654 Agronomy 119, 83-151. 
656 Liao, J.D., Boutton, T.W., Jastrow, J.D., 2006. Storage and dynamics of carbon and 657 nitrogen in soil physical fractions following woody plant invasion of grassland.

$658 \quad$ Soil Biology and Biochemistry 38, 3184-3196.

659

660 Manzoni, S., Porporato, A., 2009. Soil carbon and nitrogen mineralization: Theory and 661 662

663 Marriott, E.E., Wander, M., 2006. Qualitative and quantitative differences in particulate 664 organic matter fractions in organic and conventional farming systems. Soil Biology

666

667

Mayer, L.M., Schick, L.L., Hardy, K.R., Wagai, R., McCarthy, J., 2004. Organic matter 668

669 and Biochemistry 38, 1527-1536.

670

671

Miltner, A., Bombach, P., Schmidt-Brücken, B., Kästner, M., 2012. SOM genesis:

672

673

674 Navarro-García, F., Casermeiro, M.Á., Schimel, J.P., 2012. When structure means 675 conservation: Effect of aggregate structure in controlling microbial responses to 676 677

678 Olk, D.C., 2008. Organic forms of soil nitrogen. In: Schepers, J.S., Raun,W.R., (Eds.), 679 Nitrogen in Agricultural Systems. Agronomy Monograph 49. American Society of 680 681 682

683 Olk, D.C., Gregorich, E.G., 2006. Overview of the Symposium Proceedings, 684 685 Agronomy, Americal Society of Crop Science, Americal Scociety of Soil Science, 681 Madison, WI., pp. 57-100.

686

687 Parham, J.A., Deng, S.P., 2000. Detection, quantification and characterization of $\beta$ - 
690 Pulleman, M.M., Marinissen, J.C.Y., 2004. Physical protection of mineralizable C in

693 Schimel, J.P., Bennett, J., 2004. Nitrogen mineralization: challenges of a changing aggregates from long-term pasture and arable soil. Geoderma 120, 273-282.

695

Schimel, J.P., Weintraub, M.N., 2003. The implications of exoenzyme activity on

microbial carbon and nitrogen limitation in soil: a theoretical model. Soil Biology

699

700

701

702

703

704

705

706

707

708

709

710

711

712

713

714

715

716

717

718

719

720

$$
\text { paradigm. Ecology 85, 591-602. }
$$
and Biochemistry 35, 549-563.

Schmidt, M.W.I., Torn, M.S., Abiven, S., Dittmar, T., Guggenberger, G., Janssens, I.A., Kleber, M., Koegel-Knabner, I., Lehmann, J., Manning, D.A.C., Nannipieri, P., Rasse, D.P., Weiner, S., Trumbore, S.E., 2011. Persistence of soil organic matter as an ecosystem property. Nature $478,49-56$.

Schulten, H.R., Schnitzer, M., 1997. The chemistry of soil organic nitrogen: a review. Biology and Fertility of Soils 26, 1-15.

Six, J., Bossuyt, H., Degryze, S., Denef, K., 2004. A history of research on the link between (micro)aggregates, soil biota, and soil organic matter dynamics. Soil and Tillage Research 79, 7-31.

Six, J., Conant, R.T., Paul, E.A., Paustian, K., 2002. Stabilization mechanisms of soil organic matter: Implications for C-saturation of soils. Plant and Soil 241, 155-176.

Six, J., Elliott, E.T., Paustian, K., 2000. Soil macroaggregate turnover and microaggregate formation: A mechanism for $\mathrm{C}$ sequestration under no-tillage agriculture. Soil Biology and Biochemistry 32, 2099-2103.

Sollins, P., Homann, P., Caldwell, B.A., 1996. Stabilization and destabilization of soil organic matter: mechanisms and controls. Geoderma 74, 65-105. 
722 Thomson, B.C., Ostle, N.J., McNamara, N.P., Whiteley, A.S., Griffiths, R.I., 2010. Effects of sieving, drying and rewetting upon soil bacterial community structure 725 and respiration rates. Journal of Microbiological Methods 83, 69-73.

Toenshoff, C., Joergensen, R.G., Stuelpnagel, R., and Wachendorf, C. (2014) Initial decomposition of post-harvest crown and root residues of poplars as affected by $\mathrm{N}$ 733 availability and particle size. Biology and Fertility of Soils 50, 675-683.

\section{Vdović, N., Jurina, I., Škapin, S.D., Sondi, I., 2010. The surface properties of clay} minerals modified by intensive dry milling - revisited. Applied Clay Science 48, $575-580$.

Vranova, V., Rejsek, K., Formanek, P., 2013. Proteolytic activity in soil: A review.

Vestergaard, P., Ronn, R., and Christensen, S. (2001) Reduced particle size of plant material does not stimulate decomposition, but affects the microbivorous microfauna. Soil Biology \& Biochemistry 33, 1805-1810.

751

Wallenstein, M.D., Weintraub, M.N., 2008. Emerging tools for measuring and modeling the in situ activity of soil extracellular enzymes. Soil Biology and Biochemistry 40, 2098-2106.

Young, I., Ritz, K., 2000. Tillage, habitat space and function of soil microbes. Soil and Tillage Research 53, 201-213.

Zimmerman, A.R., Ahn, M.Y., 2011. Organo-mineral enzyme interaction and soil enzyme activity. In: Shukla, G., Varma, A. (Eds.), Soil Enzymology, Soil Biology, vol. 22. Springer-Verlag, Berlin, pp. 271-292. 


\section{Figure Legends}

754

755 Figure 1. The percentage mass of each fraction in constructed aggregated soils and 756 corresponding disaggregated soils used for the net $\mathrm{N}$ mineralization and potential enzyme 757 activity assays. Aggregated GL and AL soils were constructed by mixing $24 \mathrm{~g}$ of $4.75-$ $7582 \mathrm{~mm}, 24 \mathrm{~g}$ of $2-0.25 \mathrm{~mm}$ and $6 \mathrm{~g}$ of $0.25-0.063 \mathrm{~mm}$ fractions. Corresponding disaggregated 759 soils were prepared by disrupting the aggregates using a pestle and mortar. Data for 760 disaggregated soils are mean \pm standard errors ( $n=6$ for GL and $n=5$ for AL). There were 761 no significant differences between GL and AL for 2-0.25mm ( $P=0.115$; Welch's t-test), $7620.25-0.063 \mathrm{~mm}(P=0.066$; Welch's t-test $)$ and $<0.063 \mathrm{~mm}(P=0.925$; $\mathrm{t}$-test $)$.

763

764 Figure 2. a: Interpretation of intercept and slope parameters derived from linear

765 relationships between $\mathrm{N}$ depolymerase activity (combined protease and $\beta$ -

766 glucosaminidase) (as an estimate of the potential to produce depolymerized LMW DON 767 products) and net $\mathrm{N}$ mineralization (as a bioassay for actual production of LMW DON)

768 and their comparison between aggregated and disaggregated states to distinguish

769 between the mechanisms responsible for disaggregation-promoted $\mathrm{N}$ mineralization.

770 b: Linear regression models between $\mathrm{N}$ mineralization rate and total enzyme activity for 771 the GL+AL dataset $(n=11)$. Circles are GL soils and diamonds are AL soils. Regression 772 parameters are given in Table 3.

773

774 Figure 3. Relationship between $\mathrm{N}$ mineralization rate and total enzyme activity for 775 aggregated and corresponding disaggregated GL $(\mathbf{a}, \mathrm{n}=6)$ and $\operatorname{AL}(\mathbf{b}, \mathrm{n}=5)$ soil. 
776 Table 1 Selected initial mean properties of the constructed grassland (GL) and 777 arable (AL) soils used for $\mathbf{N}$ mineralization incubations and enzyme assays. 778 Concentrations of $\mathrm{NH}_{4}{ }^{+}-\mathbf{N}$ and $\mathrm{NO}_{3}-\mathbf{N}$ were determined for soils both prior to (A, 779 aggregated) and after disaggregation (D). Soil properties were determined for 780 aggregated soil with the exception of Total $\mathbf{C}$ and $\mathbf{N}$ for $\mathrm{AL}$ (determined for 781 disaggregated soil) and soil pH (determined for soils passing through a $2 \mathbf{~ m m}$ sieve). 782 It was assumed that properties for the disaggregated soil, given its derivation, were 783 the same as for the aggregated soil. Figures in parentheses are standard errors.

\begin{tabular}{|c|c|c|}
\hline \multirow[b]{3}{*}{ Soil Property } & \multicolumn{2}{|c|}{ Land Use } \\
\hline & GL soil $(n=6)$ & AL soil $(n=5)$ \\
\hline & & \\
\hline Land Use details & $\begin{array}{l}\text { > } 20 \text { years under permanent } \\
\text { pasture; in Entry Level } \\
\text { Stewardship Scheme. }\end{array}$ & $\begin{array}{l}>10 \text { years under arable } \\
\text { (maize/ winter wheat) } \\
\text { rotation. }\end{array}$ \\
\hline $\mathrm{N}$ fertilizer and tillage & $\begin{array}{l}\text { Limited inorganic } \mathrm{N} \\
\text { fertilizer }\left(<50 \mathrm{Kg} \mathrm{ha}^{-1}\right) \text { and } \\
\text { no organic } \mathrm{N} \text { inputs other } \\
\text { than addition by grazing } \\
\text { heifers. }\end{array}$ & $\begin{array}{l}\text { Regular tillage (ploughing/ } \\
\text { power harrow) and } \mathrm{N} \\
\text { fertilizer additions as farm } \\
\text { yard manure }\left(\sim 40 \mathrm{t} \mathrm{ha}{ }^{-1}\right) \\
\text { and foliar feeds. }\end{array}$ \\
\hline $\begin{array}{l}\text { Gravimetric Water Content } \\
\text { (air-dried soil; \%) }\end{array}$ & $6.7(1.2)$ & $0.8(0.006)$ \\
\hline Soil pH (1 soil: 2.5 H2o) & $5.95(0.0946)$ & $6.15(0.0107)$ \\
\hline \multirow[t]{2}{*}{$\mathrm{NH}_{4}^{+}(\mathrm{mg}-\mathrm{N} / \mathrm{kg} \text { OD-soil })^{\mathrm{a}}$} & A: $4.03(0.532)$ & A: $1.52(0.104)$ \\
\hline & D: $4.48(0.800)$ & D: $1.68(0.109)$ \\
\hline \multirow[t]{2}{*}{$\mathrm{NO}_{3}^{-}(\mathrm{mg}-\mathrm{N} / \mathrm{kg} \text { OD-soil })^{\mathrm{a}}$} & A: $17.8(1.76)$ & A: $27.2(3.10)$ \\
\hline & $\mathrm{D}: 18.0(1.70)$ & D: $26.1(2.64)$ \\
\hline \multirow[t]{2}{*}{ Total C (g / kg OD-soil $)^{\mathrm{b}}$} & $58.2(8.18)$ & $20.8(0.231)$ \\
\hline & $P=0 . C$ & $06^{c}$ \\
\hline \multirow[t]{2}{*}{ Total N (g / kg OD-soil $)^{\mathrm{b}}$} & $6.24(0.895)$ & $2.00(0.0311)$ \\
\hline & $P=0$. & $05^{\mathrm{c}}$ \\
\hline $\mathrm{C}$ to $\mathrm{N}$ ratio & $9.33(0.142)$ & $10.4(0.0570)$ \\
\hline Soil texture $^{\mathrm{d}}$ & Silt Loam & Sandy Loam \\
\hline
\end{tabular}




\begin{tabular}{lll} 
Clay $(\%)$ & $3.75(0.297)$ & $3.48(0.104)$ \\
Sand $(\%)$ & $31.72(3.03)$ & $51.37(0.670)$ \\
Silt $(\%)$ & $64.53(2.74)$ & $45.15(0.592)$ \\
\hline
\end{tabular}

$784{ }^{a}$ determined by $1 \mathrm{M} \mathrm{KCl}$ extraction and colorimetric continuous flow analysis (Scalar SAN++).

$785{ }^{\mathrm{b}}$ determined by elemental analysis (Thermo Flash 2000)

$786{ }^{\mathrm{c}}$ Welch's t-test

$787{ }^{\mathrm{d}}$ determined by Laser Granulometry (Mastersizer 3000)

788 
789 Table 2. The effect of aggregation status on net $\mathbf{N}$ mineralization activity, individual (protease 790 and $\beta$-glucosaminidase) and total (protease plus $\beta$-glucosaminidase) potential $\mathrm{N}$-acquiring 791 enzyme activity and native Folin Ciocalteau (FC) -reactive compounds (i.e. phenolic and other 792 antioxidant chemicals, Everette et al., 2010) in constructed soils. Data are mean \pm standard 793 error. Aggregated soils with a capital letter in common do not differ significantly when mean 794 values for GL and AL are compared. For AL protease activity, one replicate out of the five was 795 below detection limits and not significantly different from $\mathbf{0}$, thus that value was treated as $\mathbf{0}$.

\begin{tabular}{|c|c|c|c|c|}
\hline \multirow[t]{2}{*}{ Land use } & \multicolumn{2}{|l|}{ GL soil $(n=6)$} & \multicolumn{2}{|l|}{ AL soil $(n=5)$} \\
\hline & Aggregate & Disaggregate & Aggregate & Disaggregate \\
\hline Net $\mathrm{N}$ mineralization & $7.99(0.782) \mathrm{A}^{\mathrm{a}}$ & $10.6(1.33)$ & $1.52(0.129) \mathrm{B}^{\mathrm{a}}$ & $2.21(0.109)$ \\
\hline$\left(\mu \mathrm{mol} \mathrm{N} \mathrm{g}{ }^{-1}\right.$ soil $\left.240 \mathrm{~h}^{-1}\right)$ & \multicolumn{2}{|c|}{$P=0.016^{\mathrm{b}}$} & \multicolumn{2}{|c|}{$P=0.031^{\mathrm{b}}$} \\
\hline Protease activity & $0.298(0.0324) \mathrm{A}^{\mathrm{c}}$ & $0.164(0.0316)$ & $0.175(0.0487) \mathrm{A}^{\mathrm{c}}$ & $0.105(0.0357)$ \\
\hline$\left(\mu \mathrm{mol}\right.$ tyrosine equivalents $\mathrm{g}^{-1}$ soil $^{-1}$ ) & \multicolumn{2}{|c|}{$P=0.002^{\mathrm{d}}$} & \multicolumn{2}{|c|}{$P=0.244^{\mathrm{d}}$} \\
\hline$\beta$-glucosaminidase activity & $1.09(0.154) \mathrm{A}^{\mathrm{a}}$ & $1.10(0.183)$ & $0.117(0.0279) \mathrm{B}^{\mathrm{a}}$ & $0.0883(0.0171)$ \\
\hline$\left(\mu \mathrm{mol}\right.$ p-nitrophenol $\mathrm{g}^{-1}$ soil $^{-1}$ ) & \multicolumn{2}{|c|}{$P=0.924^{\mathrm{d}}$} & \multicolumn{2}{|c|}{$P=0.115^{\mathrm{d}}$} \\
\hline Protease $+\beta$-glucosaminidase acitivity & $1.39(0.180) \mathrm{A}^{\mathrm{a}}$ & $1.27(0.214)$ & $0.292(0.0261) \mathrm{B}^{\mathrm{a}}$ & $0.193(0.0360)$ \\
\hline ( $\mu \mathrm{mol}$ (tyrosine equiv. $+\mathrm{p}-$ & \multicolumn{2}{|c|}{$P=0.232^{\mathrm{d}}$} & \multicolumn{2}{|c|}{$P=0.100^{\mathrm{d}}$} \\
\hline \multicolumn{5}{|l|}{ nitrophenol) $\mathrm{g}^{-1}$ soil $^{-1}$ ) } \\
\hline FC-reactive compounds ( $\mu \mathrm{mol}$ & $0.590(0.0376) \mathrm{A}^{\mathrm{a}}$ & $0.642(0.0469)$ & $0.546(0.00975) \mathrm{A}^{\mathrm{a}}$ & $0.532(0.0197)$ \\
\hline tyrosine equivalents $\mathrm{g}^{-1}$ soil $\mathrm{h}^{-1}$ ) & \multicolumn{2}{|c|}{$P=0.191^{\mathrm{d}}$} & \multicolumn{2}{|c|}{$P=0.593^{\mathrm{d}}$} \\
\hline
\end{tabular}

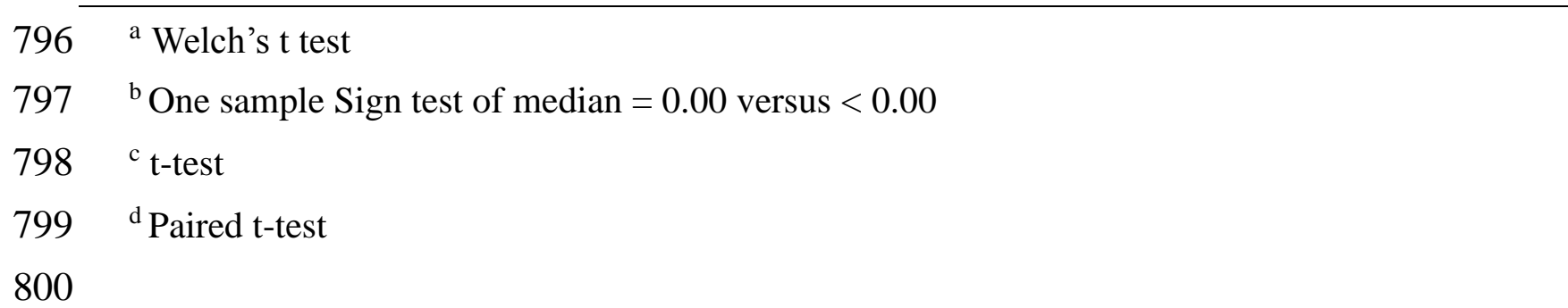


801 Table 3. Coefficients and their $\mathbf{P}$ values for regression models shown in Figs.

$802 \quad 2 b$ and 3.

\begin{tabular}{clllll}
\hline & & Aggregate & \multicolumn{2}{l}{ Disaggregate } \\
\hline GL+AL & Adjusted $\mathrm{R}^{2}$ & 0.89 & & 0.95 & \\
& Gradient & 5.29 & $\mathrm{P}<0.001$ & 7.22 & $\mathrm{P}<0.001$ \\
& Intercept & 0.33 & $\mathrm{P}=0.616$ & 1.19 & $\mathrm{P}=0.048$ \\
\hline $\mathrm{GL}$ & Adjusted $\mathrm{R}^{2}$ & 0.47 & & 0.86 & \\
& Gradient & 3.30 & $\mathrm{P}=0.081$ & 5.84 & $\mathrm{P}=0.005$ \\
& Intercept & 3.40 & $\mathrm{P}=0.173$ & 3.24 & $\mathrm{P}=0.085$ \\
\hline & Adjusted $\mathrm{R}^{2}$ & 0.22 & & 0.24 & \\
& Gradient & 3.19 & $\mathrm{P}=0.435$ & 2.01 & $\mathrm{P}=0.227$ \\
& Intercept & 0.59 & $\mathrm{P}=0.241$ & 1.82 & $\mathrm{P}=0.007$ \\
\hline
\end{tabular}

803 